\title{
Evaluation of the relationship between the prevalence of diabetes and selected demographic factors
}

\section{ABSTRACT}

Introduction. Global incidence of diabetes is rising rapidly. It is associated with the increasing incidence of overweight and obesity as well as population ageing. The aim of the study is to examine the prevalence of diabetes among adult residents of a typical eastern Poland district and to determine the relationship between the prevalence of diabetes and selected sociodemographic factors.

Material and methods. The study involved 1225 residents of the Janów Lubelski district aged between 36 and 65 years. The research methodology for this study included a questionnaire survey. Statistical analysis was performed. Subjects were categorized into 5-year age range groups.

Results. The prevalence of diabetes in the study population is $4.7 \%$. The study shows that the frequency of diabetes increases with age. The prevalence of diabetes in each age group is as follows: $0.6 \%(36-40) ; 1.5 \%(41-$ $-45) ; 2.0 \%$ (46-50); $5.1 \%$ (51-55); $6.4 \%$ (56-60); $11.4 \%$ (61-65). Higher prevalence of diabetes is observed in men as compared to women ( $6.6 \%$ vs. $3.5 \%$ ), in subjects with lower educational background as compared to subjects with higher educational background as well as in unmarried men as compared to married ones.

Address for correspondence:

prof. dr hab. n. med. Grzegorz Dzida

Katedra i Klinika Chorób Wewnętrznych

Uniwersytet Medyczny w Lublinie

Translation: Meddea

e-mail: grzegorz.dzida@wp.pl

Clinical Diabetology 2018, 7, 3, 145-150

DOI: $10.5603 /$ DK.2018.0010

Received: 22.01.2018

Accepted: 13.02 .2018
Rural vs. urban residence and the marital status of women have no effects on the prevalence of diabetes. Conclusion. The results of the study suggest that sociodemographic factors such as gender, age, and education have an important influence on the prevalence of diabetes. Marital status also appears to be an influential factor. (Clin Diabetol 2018; 7, 3: 145-150)

Key words: diabetes, DM, prevalence, sociodemographic factors

\section{Introduction}

For many years, the incidence of diabetes has been increasing at a rate much higher than previously anticipated. In the year 2000, the International Diabetes Federation (IDF) and the World Health Organization (WHO) estimated that the total number of patients with diabetes worldwide was 151 to 171 million. In their reports published in that year, both organizations predicted this number to increase to 324-366 million by year 2030 [1, 2]. However, according to the most recent IDF report for the year 2017, the total population of diabetes patients has already exceeded the predicted numbers and amounts to about $\mathbf{4 2 5}$ million individuals [3]. This increase is associated with the increasing incidence of overweight and obesity as well as population ageing. Since type 2 diabetes mellitus may be asymptomatic in some patients, it may remain undiagnosed for long periods. The percentage of nondiagnosed patients in Europe is about $37.9 \%$. In Poland, this percentage is in the range of about $22-33 \%[3,4]$. Therefore, active screening for diabetes, particularly in high risk groups, is very important. Blood glucose tests 
are becoming more and more widespread, contributing to the continuous decrease in the number of individuals who had never undergone this type of examination. Nearly one half of adult residents of Poland declares having been screened for diabetes during the last 12 months; in the case of elderly subjects (60 years or more), the percentage may reach as much as $70 \%$ [5].

The aim of this study was to examine the prevalence of diabetes among adult residents of a typical eastern Poland district (aged 36-65 years) and to determine the relationship between the prevalence of diabetes and selected sociodemographic factors including gender, age, educational background, area of residence and marital status.

\section{Material and methods}

The study was conducted in years 2009-2016 as part of free public health promotion project titled "Take Your Health to Your Heart", financed by the Norway Grants. The study was aimed at analyzing the health status of the residents of the Janów Lubelski district within the Lublin voivodeship, at identifying the residents' needs with regard to the reduction of cardiovascular risk, and at taking appropriate measures to reduce inequalities in health chances as compared to more affluent regions of Poland. The research methodology for this study included a questionnaire survey. The first part of the questionnaire consisted of questions pertaining to selected sociodemographic data (gender, age, educational background, area of residence, marital status) while the second part surveyed the medical history and current health of subjects. A total of 1225 residents of the Janów Lubelski district, aged 36 to 65 , reported to take part in the study. The results were processed using the MS Office 2007 suite and the Statistica StatSoft package (academic license for the Lublin University of Technology). For a more detailed analysis of results, the subjects were subcategorized into 5-year age range groups $(36-40,41-45,46-50,51-55,56-60,61-65)$. The relationship between the prevalence of diabetes and the sociodemographic factors (gender, age, educational background, area of residence, marital status) was analyzed using the chi-square test of independence and $p<0.05$. The results are presented with the accuracy of one decimal place (0.1).

\section{Results}

The study was conducted in 1225 subjects aged 36 to 65 years, with $60.6 \%$ (742) subjects being female and the remaining $39.4 \%$ (483) subjects being male. The number of subjects in individual age groups is presented in Table 1.
Table 1 . The study population subcategorized by gender and age

\begin{tabular}{lccc}
\hline \multirow{2}{*}{ Age range } & \multicolumn{2}{c}{ Gender } & Overall \\
\cline { 2 - 3 } & Women & Men & \\
\hline $36-40$ & 94 & 69 & 163 \\
$41-45$ & 129 & 77 & 206 \\
$46-50$ & 127 & 72 & 199 \\
$51-55$ & 116 & 81 & 197 \\
$56-60$ & 147 & 103 & 250 \\
$61-65$ & 129 & 81 & 210 \\
Overall & 742 & 483 & 1225 \\
\hline
\end{tabular}

Table 2. Characteristic of study population

\begin{tabular}{lcc}
\hline & Number & Percentage \\
\hline Area of residence & & \\
$\quad$ Rural & 620 & $50.6 \%$ \\
Urban & 605 & $49.4 \%$ \\
Overall & 1225 & \\
Educational background & & \\
$\quad$ Elementary & 99 & $8.1 \%$ \\
Vocational & 386 & $31.5 \%$ \\
Secondary & 416 & $34.0 \%$ \\
Higher & 324 & $26.4 \%$ \\
$\quad$ Overall & 1225 & \\
Marital status & & \\
Married & 1070 & $87.3 \%$ \\
Single & 155 & $12.7 \%$ \\
Overall & 1225 & \\
\hline
\end{tabular}

The numbers of urban and rural residents were comparable and amounted to $49.4 \%$ and $50.6 \%$, respectively. The highest percentages of subjects had secondary or vocational educational background (34.0\% and $31.5 \%$, respectively). Most subjects within the study populations (87.3\%) were married (Table 2).

The overall number of patients in the study group of 1225 subjects aged $36-65$ years was 58 , corresponding to $4.7 \%$ of the population. The lowest percentage of patients with diabetes, amounting to $1.4 \%$, was observed in patients between 36 and 50 years of age. The respective percentages in individual 5 -year ranges were $0.6 \%(1 / 163)$ for subjects aged $36-40 ; 1.5 \%$ (3/206) for subjects aged 41-45; and 2.0 (4/199) for subjects aged $46-50$. In older patients, the average percentage of patients was 4.7 and was significantly higher than in the previously mentioned group. The respective percentages in individual 5 -year ranges were $5.1 \%(10 / 197)$ for subjects aged $51-55 ; 6.4 \%(16 / 250)$ 


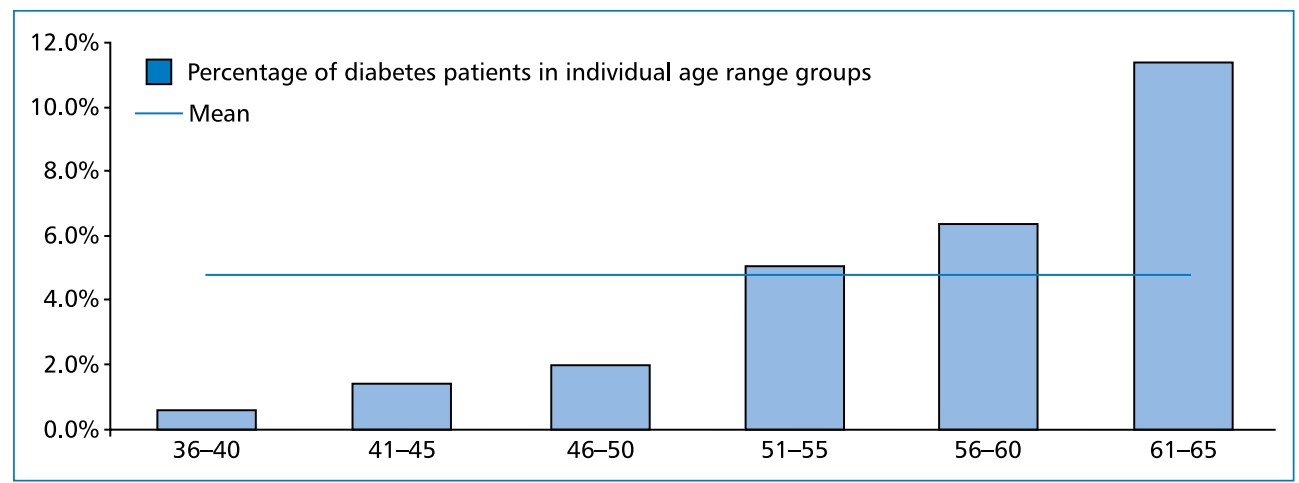

Figure 1. The percentages of patients with diabetes in individual age range groups. Blue line indicates the population mean

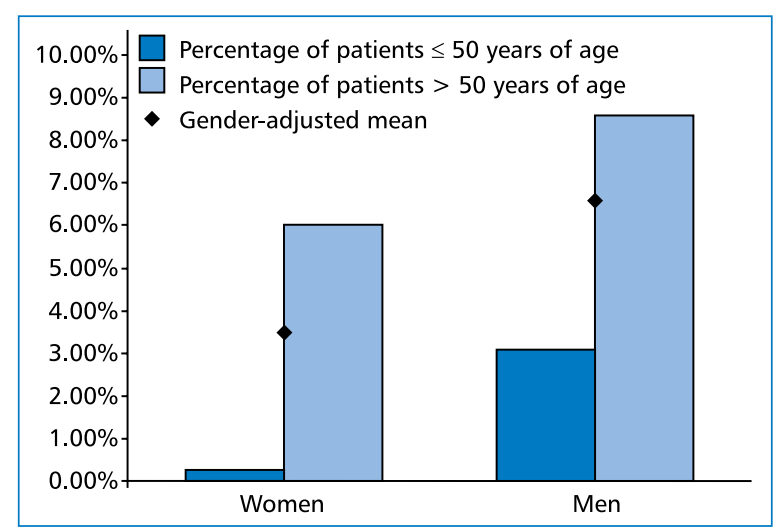

Figure 2. The percentage of diabetes patients in the male and female subpopulations

for subjects aged 56-60; and $11.4 \%(24 / 210)$ for subjects above the age of $60(p<0.005)$. The results are presented in Figure 1.
A statistically significant difference was observed in the prevalence of diabetes in men and women. The percentage of patients was higher in men $(6.6 \% ; 32 / 483)$ as compared to women $(3.5 \% ; 26 / 742)(p=0.01)$. In women, the percentage of diabetes patients was $0.3 \%$ below the age of 50 and significantly increased after this age to reach $6.0 \%(p<0.01)$. In the male population, diabetes was observed in $3.1 \%$ of subjects below the age of 50 , while the respective percentage in the group of patients above the age of 50 was nearly 3 times higher and amounted to $8.6 \%$ $(p=0.01)$ (Figure 2).

The relationship between the prevalence of diabetes and the educational background was analyzed to show that higher education was correlated with lower prevalence of diabetes in the study population ( $p=0.05$ ). Among the individuals with higher education, the percentage of diabetes patients was lower (2.2\%) compared to subjects with elementary $(6.1 \%)$, vocational (6.5\%), or secondary education (4.8\%) (Figure 3 ).

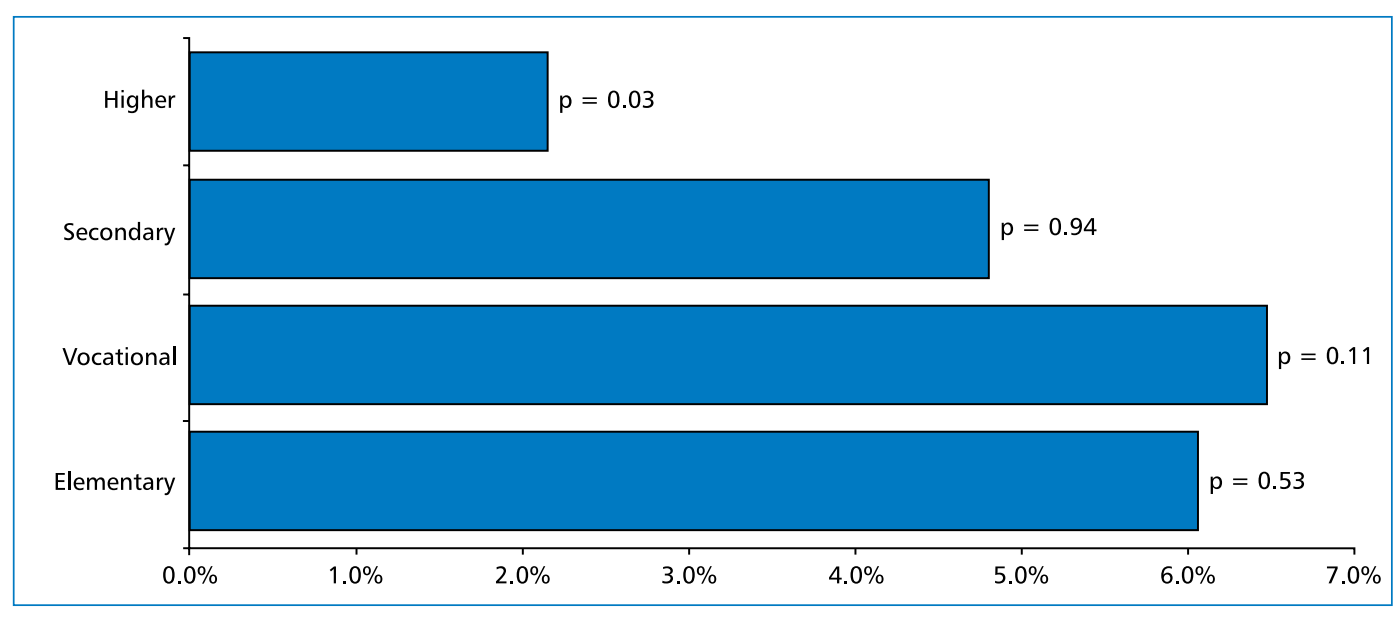

Figure 3. Prevalence of diabetes vs. educational background of subjects. The chart presents the statistical significance levels for all groups 


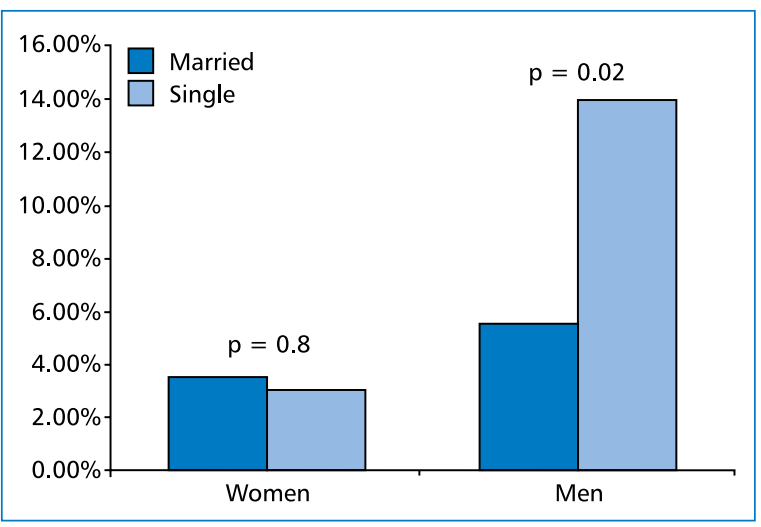

Figure 4. Prevalence of diabetes vs. marital status of subjects

The prevalence of diabetes in urban vs. rural residents was comparable. Diabetes had been diagnosed in $3.9 \%$ of rural residents as compared to $5.6 \%$ of urban residents. The study revealed no association between the area of residence (rural vs. urban) and the prevalence of diabetes $(p=0.16)$.

No influence of marital status on the prevalence of diabetes was observed when comparing the subpopulation of married women with that of non-married (unmarried, divorced, widowed) women ( $p=0.8)$. On the other hand, a statistically higher percentage of diabetes patients was observed in non-married men (unmarried, divorced, widowed) $(14.0 \% ; 8 / 57)$ as compared to married men $(5.6 \% ; 24 / 426)(p=0.02)$ (Figure 4).

\section{Discussion}

Since no diabetes patient registry is available in Poland, no reliable epidemiological analyses can be performed and the estimation of the prevalence of diabetes in Polish population is possible only on the basis of epidemiological studies conducted every several years. The number of multicenter studies in representative samples of the Polish population is limited; the analysis of results obtained in the largest epidemiological studies conducted in Poland in recent years and including the assessment of diabetes prevalence is presented in Table 3.

Age and gender are non-modifiable risk factors of type 2 diabetes. According to the IDF report, the incidence of diabetes based on the worldwide data is higher in men as compared to women (9.1\% vs. 8.4\%) [3]. As shown by results of studies presented in Table 3 and the results of our own study, the prevalence of diabetes in men as compared to women is also higher in Poland. Slight differences in the prevalence of diabetes in men and women were observed in the Poland's population health survey conducted by Statistics Poland (GUS) in 2014. According to the survey results, established diabetes was reported by $6.4 \%$ of women and $6.9 \%$ of men [5]. However, this relationship is inverted in elderly subjects since, as shown in the WOBASZ Senior study conducted in subjects $\geq 75$ years of age, the prevalence among women is higher than that among men [7]. In general, the risk of type 2 diabetes mellitus increases with age, with the prevalence in subjects above the age of 50 significantly exceeding the all-population mean (data on file $[3,4,8]$ ). In the elderly patients above the age of 75 , the prevalence is as high as $21.9 \%$ [8].

Socioeconomic status is another influential factor, with the educational background being one of its most important determinants. Lower educational background is associated not only with poorer health control and outcomes of treatment and prevention of complications in chronic diseases, but also with lower awareness of healthy lifestyle [11, 12]. Statistically, individuals with higher education have higher life expectancy due to their higher awareness of the principles of healthy nutrition, the importance of physical activity, the consequences of overweight and obesity as well as smoking. Over the recent dozen or so years, the educational profile of Poland's population has

Table 3. Epidemiological studies on the prevalence of diabetes in Poland

\begin{tabular}{|c|c|c|c|c|c|c|}
\hline \multirow[t]{2}{*}{ Study } & \multirow[t]{2}{*}{ Year } & \multicolumn{3}{|c|}{ Prevalence of diabetes } & \multirow[t]{2}{*}{ Age of subjects } & \multirow[t]{2}{*}{ Reference } \\
\hline & & Women & Men & Overall & & \\
\hline WOBASZ I & 2003-2005 & $6.1 \%$ & $7.5 \%$ & $6.8 \%$ & $20-74$ & {$[4,6]$} \\
\hline WOBASZ Senior & 2007 & $18.8 \%$ & $16.9 \%$ & $17.9 \%$ & $>74$ & {$[7]$} \\
\hline PolSenior & $2007-2011$ & $\begin{array}{l}17.9 \% \\
4.0 \%\end{array}$ & $\begin{array}{c}\text { Diagnosed } \\
\text { Undiagnosed }\end{array}$ & $21.9 \%$ & $>64$ & [8] \\
\hline NATPOL 2011 & 2011 & $\begin{array}{l}6.4 \% \\
12 \%\end{array}$ & $\begin{array}{c}7.0 \% \\
15.8 \%\end{array}$ & $\begin{array}{c}6.7 \% \\
13.8 \%\end{array}$ & $\begin{array}{l}18-79 \\
45-79\end{array}$ & {$[9,10]$} \\
\hline WOBASZ II & 2014 & $8.4 \%$ & $11.4 \%$ & $9.8 \%$ & $20-74$ & {$[6]$} \\
\hline
\end{tabular}




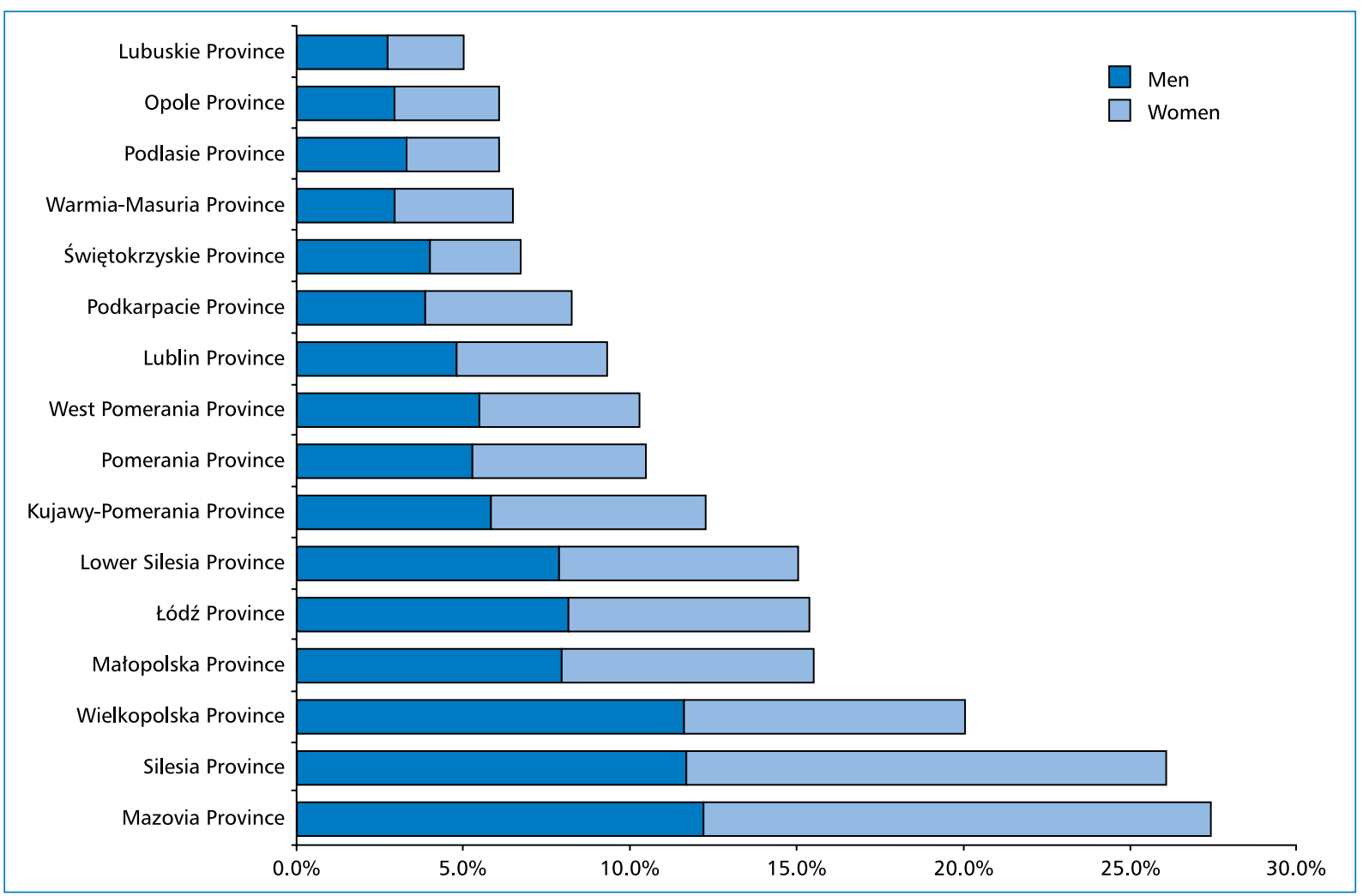

Figure 5. Diabetes prevalence rates in individual voivodeships; own work based on the Statistics Poland data from 2004 [18]

changed favorably, and the percentage of individuals with higher education is increasing [13].

In Poland, significant discrepancies in the prevalence of diabetes are observed between individual voivodeships. This may be due, among other factors, to the differences in rural vs. urban residence distributions, nutrition habits, physical activity, lifestyle, or health care access. According to the IDF studies, the prevalence of diabetes among urban residents is higher than that among rural residents (10.2\% vs. 6.9\%) [3]. Lublin voivodeship is characterized by one of the lowest urbanization rates (the percentage of urban residents in the overall population) [14]. The low urbanization rate does not appear to have a negative impact on the level of health care in the region - the voivodeship's number of practicing physicians in health care centers, the number of beds in stationary hospitals and the number of outpatient health care centers per 10,000 residents rank among the country's highest $[13,15]$. What's more, according to a study by the Department of Analyses and Strategy of the Ministry of the Health, the prevalence of diabetes among the residents of the Lublin voivodeship is significantly lower compared to other voivodeships. Amounting to 3339.93 cases per 100,000 residents, it is the second lowest in the country (the lowest amounting to 3162.30 for Wielkopolska
Province and the largest amounting to 4560.41 for Silesian voivodeship). Also the standardized mortality rate for diabetes (E10-E12 acc. to ICD-10) in the Lublin voivodeship is 3.3 percentage points lower than the all-country one. The Janów Lubelski district where the study presented in this article was performed, is characterized by one of the voivodeship's lowest rates of hospital morbidity and outpatient specialist care rates for diabetes, low standardized mortality rate for diabetes, and the lowest number of primary health care physicians' services per the insured [16].

Significant differences in the prevalence of diabetes were also observed between individual voivodeships in the WOBASZ I study where the morbidity rates ranged from 4.2\% (Małopolska Province) to 7.5\% (Wielkopolska Province) in women and from 5.3\% (Subcarpathian) to $9.0 \%$ (Wielkopolska Province). The respective rates for the Lublin voivodeship were $6.2 \%$ and $7.0 \%$ [4].

Statistic Poland's data on the prevalence of established diabetes cases in individual voivodeships in year 2004 are presented in Figure 5. Similar results were obtained by Walicka et al. who assessed the numbers of patients in the National Health Fund's database who were identified as suffering from type 2 diabetes mellitus (on the basis of the ICD-10 code) in the years 2010-2014. The mean percentage of patients diag- 
nosed with diabetes was $4.47 \%$ as compared to $4.3 \%$ for the Lublin voivodeship. The lowest rates in this study were determined for Warmian-Masurian (3.5\%) and Subcarpathian voivodeships (3.6\%) while the highest one was observed in Silesian voivodeship (5.5\%) [17].

In summary, the results of the study suggest that sociodemographic factors such as gender, age, and education have an important influence on the prevalence of diabetes. Marital status also appears to be an influential factor. The presented study suggests that the incidence of diabetes increases with age, male gender, worse educational background, and non-married status in men. Rural vs. urban residence or the marital status in women were found to have no impact on the morbidity rates. The prevalence of diabetes in the study population was $4.7 \%$ and was lower compared to the results of studies presented in the discussion part. However, one should keep in mind that the results presented in this study relate to the confirmed cases only, and that diabetes may remain undiagnosed in some patients. In addition, the study was conducted in the Janów Lubelski district of the Lublin voivodeship, i.e. in a region characterized by a diabetes morbidity rate being low as compared to the entire country. Multicenter studies covering the entire area of Poland are required to establish the prevalence on the countrywide scale. This study is only a reflection of the epidemiological situation in a particular region of the Lublin voivodeship. An additional limitation of this study consists in its retrospective character and survey-based methodology.

\section{Conflicts of interests}

The authors declare no conflicts of interests.

The study was conducted as part of the project titled "Take Your Health to Your Heart - a health promotion and cardiovascular disease prevention program for the Janów Lubelski district", supported through the Norwegian Financial Mechanism as part of the PL 13 Task "Reducing health inequalities" for years 2009-2014 and the state budget funds.

\section{REFERENCES}

1. IDF Diabetes. 1st ed. Brussels: International Diabetes Federation International Diabetes Federation. http://www.diabetesatlas. org (2000).
2. Wild S, Roglic G, Green A, et al. Global prevalence of diabetes: estimates for the year 2000 and projections for 2030. Diabetes Care. 2004; 27(5): 1047-1053, doi: 10.2337/diacare.27.5.1047, indexed in Pubmed: 15111519.

3. DF Diabetes. 8th ed. Brussels: International Diabetes Federation. International Diabetes Federation. http://www.diabetesatlas. org (2017).

4. Polakowska M, Piotrowski W. Incidence of diabetes in the Polish population: results of the Multicenter Polish Population Health Status Study - WOBASZ. Pol Arch Med Wewn. 2011; 121(5): 156-163, indexed in Pubmed: 21610663.

5. Główny Urząd Statystyczny. Stan zdrowia ludności Polski w 2014 r. Warszawa, 2016.

6. Drygas W, Bielecki W, Kozakiewicz K, Pająk A, Piotrowski W. Wieloośrodkowe Ogólnopolskie Badanie Stanu Zdrowia Ludności - WOBASZ. Epidemiologia i prewencja chorób układu krążenia. Medycyna Praktyczna, Kraków 2015.

7. Piotrowski W, Waśkiewicz A, Cicha-Mikołajczyk A. Global cardiovascular mortality risk in the adult Polish population: prospective assessment of the cohorts studied in multicentre national WOBASZ and WOBASZ Senior studies. Kardiol Pol. 2016; 74(3): 262-273, doi: 10.5603/KP.a2015.0175, indexed in Pubmed: 26365939.

8. Januszkiewicz-Caulier J, Mossakowska M, Zdrojewski T, Ślusarczyk P, Broczek K, Chudek J. Cukrzyca i jej powikłania w podeszłym wieku. PolSenior. Aspekty medyczne, psychologiczne i ekonomiczne starzenia się ludzi w Polsce. Termedia, Poznań 2012.

9. Zdrojewski T, Rutkowski M, Bandosz P, Gaciong Z, Solnica B. Ocena rozpowszechnienia i kontroli czynników ryzyka chorób serca i naczyń w Polsce - badania NATPOL 1997, 2002, 2011. Epidemiologia i prewencja chorób układu krążenia. Medycyna Praktyczna, Kraków 2015

10. Rutkowski M, Bandosz P, Czupryniak $L$, et al. Prevalence of diabetes and impaired fasting glucose in Poland - the NATPOL 2011 Study. Diabet Med. 2014; 31(12): 1568-1571, doi: 10.1111/ /dme.12542, indexed in Pubmed: 24975751.

11. Agardh E, Allebeck P, Hallqvist J, et al. Type 2 diabetes incidence and socio-economic position: a systematic review and metaanalysis. Int J Epidemiol. 2011; 40(3): 804-818, doi: 10.1093/ije/ /dyr029, indexed in Pubmed: 21335614.

12. Sacerdote C, Ricceri F, Rolandsson O, et al. Lower educational level is a predictor of incident type 2 diabetes in European countries: the EPIC-InterAct study. Int J Epidemiol. 2012; 41(4): 1162-1173, doi: 10.1093/ije/dys091, indexed in Pubmed: 22736421.

13. Wojtyniak B, Goryński P. Sytuacja zdrowotna ludności Polski i jej uwarunkowania. Narodowy Instytut Zdrowia Publicznego — Państwowy Zakład Higieny, Warszawa 2016.

14. Atlas Demograficzny Polski. Warszawa: Główny Urząd Statystyczny; Warszawa, 2017.

15. Zdrowie i ochrona zdrowia w 2016 r. Warszawa: Główny Urząd Statystyczny Warszawa, 2017

16. Mapa potrzeb zdrowotnych w zakresie cukrzycy dla województwa lubelskiego. Biuletyn Informacji Publicznej Ministerstwa Zdrowia. 2018. http://www.mpz.mz.gov.pl (Accessed 12/01/2018).

17. Walicka M, Chlebus M, Brzozowska M, et al. Prevalence of diabetes in Poland in the years 2010-2014. Clinical Diabetology. 2016; 4(6): 232-237, doi: 10.5603/dk.2015.0031.

18. Stan zdrowia ludności Polski w przekroju terytorialnym 2004. Warszawa: Główny Urząd Statystyczny; Warszawa, 2004. 